


\section{Judicial tribunals \\ in England and Europe, \\ 1200-1700}

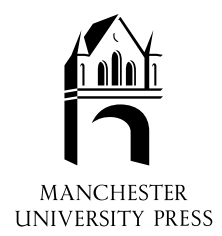


Maureen Mulholland and Brian Pullan - 9781526137463 Downloaded from manchesterhive.com at 04/26/2023 02:02:39AM 


\title{
Judicial tribunals in England and Europe, 1200-1700
}

\author{
The trial in history, volume I \\ edited by Maureen Mulholland \\ and Brian Pullan \\ with Anne Pullan
}

\author{
Manchester University Press \\ Manchester and New York \\ distributed exclusively in the USA by Palgrave
}


Copyright () Manchester University Press 2003

While copyright in the volume as a whole is vested in Manchester University Press, copyright in individual chapters belongs to their respective authors, and no chapter may be reproduced wholly or in part without the express permission in writing of both author and publisher.

Published by Manchester University Press Oxford Road, Manchester M13 9NR, UK and Room 400, 175 Fifth Avenue, New York, NY 10010, USA www.manchesteruniversitypress.co.uk

Distributed exclusively in the USA by Palgrave, 175 Fifth Avenue, New York, NY 10010, USA

Distributed exclusively in Canada by UBC Press, University of British Columbia, 2029 West Mall, Vancouver, BC, Canada V6T $1 \mathrm{Z2}$

British Library Cataloguing-in-Publication Data

A catalogue record for this book is available from the British Library

Library of Congress Cataloging-in-Publication Data applied for

ISBN 0719063426 hardback

First published 2003

$1009080706050403 \quad 10987654321$

Typeset in Photina

by Graphicraft Limited, Hong Kong

Printed in Great Britain

by Bookcraft (Bath) Ltd, Midsomer Norton 